\title{
Construction, expression, functional characterization and practical application of fusion protein SPA-BAPmut
} \author{
Kordium $^{1,2}$ \\ ${ }^{1}$ State Institute of Genetic and Regenerative Medicine, NAMS of Ukraine \\ 57/3, Chervonoarmiyska Str., Kyiv, Ukraine, 03150 \\ ${ }^{2}$ Institute of Molecular Biology and Genetics, NAS of Ukraine \\ 150, Akademika Zabolotnoho Str., Kyiv, Ukraine, 03680 \\ ${ }^{3}$ National Aviation University \\ 1, Komarova Ave., Kyiv, Ukraine, 03058 \\ gorbatuyk@ukr.net
}

O. B. Gorbatiuk ${ }^{1}$, O. V. Okunev ${ }^{1,2}$, Yu. S. Nikolaev ${ }^{1}$, O. V. Svyatenko, , , V. A.

\begin{abstract}
Aim. The creation of genetically engineered fusion protein SPA-BAPmut and its application as a secondary immunoreagent in immunoassays. Methods. Gene cloning, PCR, electrophoresis, DNA sequencing, bacteria cells culturing, protein expression and purification, ELISA, Western-blotting were used. Results. The DNA sequences encoding Staphylococcus aureus protein A (SPA) and bacterial alkaline phosphatase with enhanced catalytic activity (BAPmut) were used for construction of gene encoding fusion protein SPA-BAPmut that was expressed in the high-productive Escherichia coli system and obtained in a soluble form. Cultivation conditions to provide a high-level expression of SPA-BAPmut $>1 \mathrm{~g} / \mathrm{l})$ were determined. The target protein was obtained with purity more than $95 \%$ using IMAX method. SPA-BAPmut is thermostable, and both parts of fusion protein (SPA and BAPmut) retain their IgG binding and alkaline phosphatase activity for a long time. SPA-BAPmut was used as a substitute of secondary an- tibodies in immunoassays. As little as $5 \mathrm{ng}$ of the antigen could be detected in Western blotting and $1 \mu \mathrm{g} / \mathrm{ml}$ of IgG in ELISA. Conclusions. The possibility of using SPA-BAPmut as universal secondary immunoreagent for different types of immunoassays was shown.
\end{abstract}

Keywords: protein A, bacterial alkaline phosphatase, fusion protein, immunoassays.

Introduction. Staphylococcus aureus protein A (SPA) consists of five immunoglobulin-binding domains (E, $\mathrm{D}, \mathrm{A}, \mathrm{B}, \mathrm{C})$, each of them being capable of specific interaction with Fc-fragments of IgG of different animal species and humans [1]. Therefore, SPA is widely used in affinity chromatography to create sorbents for purification of antibodies or separation of blood of patients with autoimmune diseases from autoantibodies and circulating immune complexes [2, 3]. Another promising approach in SPA application is diagnostics. The SPA conjugates with alkaline phosphatase, horseradish peroxidase and stained iodine are used in immunological tests. This conjugation is

(C) Institute of Molecular Biology and Genetics, NAS of Ukraine, 2013 usually conducted chemically. However chemical conjugation has a number of disadvantages: 1) a great number of required purified components; 2) high heterogeneity of the final product; 3) necessity of separating full-size conjugates from non-conjugated components. In turn, the recombinant DNA technology assures the elaboration of genetic constructions, which can be used to obtain chimeric bifunctional proteins in heterological systems, including Escherichia coli.

The bacterial alkaline phosphatase with enhanced catalytic properties (BAPmut) was selected for fusion with SPA. An increase in the BAPmut catalytic activity was achieved via two aminoacid substitutes D153G and D330N (substitution of aspartic acid for asparagine and glycine in positions 153 and 330 respectively) [4]. 
Materials and Methods. Construction and expression of SPA-BAPmut. DNA-sequence of SPA was obtained via PCR-amplification from chromosomal DNA of $S$. aureus, isolated using Genomic DNA Purification Kit (Fermentas, Lithuania). A pair of specific primers, introducing restriction sites $\mathrm{NdeI}$ and NotI, was used to conduct PCR. The purified PCR product ( $\sim 880$ b.p.) was hydrolyzed by respective restrictases and cloned into plasmid vector $p E T-24 a$ (resulting plasmid $-p E T S P A$ ) [5].

PCR was conducted using the following pair of primers: sense SPA - NdeI:

5'-ATCATATGGCGCAACACGATGAAGCTCAAC-3'; antisense SPA - NotI:

\section{5'-ATGCGGC CGCTTCCT CTTTTGGTGC-3'.}

Plasmid $p C A N T A B-S c F v-B A P m u t$ and a pair of primers, introducing restriction sites NotI and XhoI, were used to obtain DNA sequences, encoding BAPmut. The purified PCR product ( 1360 b.p.) was hydrolyzed by respective restrictases and subcloned into plasmid vector $p E T-S P A$. PCR was conducted using the following pair of primers: sense BAPmut - NotI:

5'-ACGGGCGGCCGCTACACCAGAA-3'; antisense BAPmut - XhoI: 5'CGGCGAGACCCCGACTTTGAGCTCACTA-3'.

For the expression of SPA-BAPmut, E. coli BL21 (DE3) cells were transformed by obtained plasmid pET24-SPA-BAPmut. The Protein expression was induced by the autoinduction protocol [6]. The localization and content of the target protein in the total lysate of cells-producents were determined by electrophoretic separation of the soluble and insoluble fractions of cell cytoplasm proteins.

The purification of SPA-BAPmut was performed by Immobilized-metal affinity chromatography (IMAC) in native conditions. $1 \mathrm{ml}$ HiTrap chelating column balanced with $\mathrm{Ni}^{2+}$ ions was connected to an FPLC system (Pharmacia), equilibrated with the buffer (100 $\mathrm{mM}$ tris- $\mathrm{HCl}(\mathrm{pH} 8.0), 300 \mathrm{mM} \mathrm{NaCl}, 10 \mathrm{mM}$ imidazole) with the flow rate of $0.5 \mathrm{ml} / \mathrm{min}$ and a fraction of soluble proteins of cytoplasm of E.coli cells previously filtered through $0.45 \mu \mathrm{m}$ - membrane PVDF filter (Millipore, USA) was added. The column was washed from non-specifically bound proteins by the mentioned buffer until the recording pen got to the baseline. SPA-BAPmut was eluted by the buffer -100
$\mathrm{mM}$ tris- $\mathrm{HCl}(\mathrm{pH} 8.0), 300 \mathrm{mM} \mathrm{NaCl}, 300 \mathrm{mM}$ imidazole. The purified protein was dialyzed against the buffer, containing $100 \mathrm{mM}$ tris- $\mathrm{HCl}(\mathrm{pH} 9.5), 140$ $\mathrm{mM} \mathrm{NaCl}, 15 \mathrm{mM} \mathrm{MgSO}_{4}$. The homogeneity of the purified protein was analyzed in 12\% SDS-PAAG [7], SPA-BAPmut concentration was determined using the known value of $\mathrm{A}_{280}$ adsorption, calculated from this sequence using Vector NTI software.

The application of SPA-BAPmut as a secondary immunoreagent. Antibody-dependent ELISA. rhIFNa2b (PharmBiotec Scientific Production Company, Ukraine) in $50 \mathrm{mM} \mathrm{Na}$-carbonate buffer ( $\mathrm{pH} 9.5$ ) in the concentration of $10 \mu \mathrm{g} / \mathrm{ml}$ was added to the wells of polystyrene plate for ELISA (Nunc, Denmark) and incubated for $1 \mathrm{~h}$ at $37^{\circ} \mathrm{C}$. After washing the wells with PBST buffer, the affinity purified rabbit polyclonal anti-rhIFNб2 $b$ antibodies in the concentration range of $100-0.1 \mu \mathrm{g} / \mathrm{ml}$ and SPA-BAPmut, $0.5 \mu \mathrm{g} / \mathrm{ml}$, were added. The obtained immune complexes were visualized using $p$-nitrophenylphosphate, (pNPP, Sigma, USA). After staining the reaction was terminated by the introduction of $1 \mathrm{M} \mathrm{NaOH}$ and $\mathrm{A}_{405}$ adsorption value was measured using multichannel photometer Multiscan MCC/340 (Titertek, USA).

Antigen-dependent ELISA. rhIFN62b in $50 \mathrm{mM}$ Na-carbonate buffer ( $\mathrm{pH} 9.5$ ) in the concentration of 1-500 ng per well was added to the wells of polystyrene plate for ELISA (Nunc) and incubated for $1 \mathrm{~h}$ at $37^{\circ} \mathrm{C}$. After washing the wells with PBS buffer which contains $0.1 \%$ twin-20 (PBST), the affinity purified rabbit polyclonal anti-rhIFN62b antibodies [8] in the concentration $1 \mu \mathrm{g} / \mathrm{ml}$ and SPA-BAPmut in the concentration $0.5 \mu \mathrm{g} / \mathrm{ml}$, were added.

Dot-blot analysis. Antigen rhIFN62b in the amount of 5-20 ng was applied to the nitrocellulose membrane Hybond-C Extra (Amersham Biosciences, UK). After blocking the sites of non-specific binding by buffer PBS $+3 \%$ milk (PBSM), the membrane with immobilized proteins was incubated for $1 \mathrm{~h}$ with purified rabbit polyclonal anti-rhIFN62b antibodies in the concentration of $1 \mu \mathrm{g} / \mathrm{ml}$. Antigen rhExCD34 was applied onto the membrane as a negative control [9]. The target protein was detected using SPA-BAPmut in the concentration of $0.5 \mu \mathrm{g} / \mathrm{ml}$. For visualization of immune complexes Alkaline Phosphatase chromogen substrate BCIP-T/NBT (Sigma) was used. 
The determination of the thermostability of the fusion protein SPA-BAPmut. The aliquotes of the purified SPA-BAPmut $(1 \mathrm{mg} / \mathrm{ml}$ in the buffer of $0.1 \mathrm{M}$ tris- $\mathrm{HCl}$ ( $\mathrm{pH}$ 9.5), $0.14 \mathrm{M} \mathrm{NaCl}, 15 \mathrm{mM} \mathrm{MgSO}_{4}$ ) were incubated at the following temperatures: $+4,+50,+70$, $+85,+95,-20,-70^{\circ} \mathrm{C}$ for $10 \mathrm{~min}$. The enzymatic activity of the alkaline phosphatase and IgG-binding activity of protein A were determined in ELISA.

Results and Discussion. In addition to affinity chromatography, the application of SPA, fused with the marker molecule, is promising for the determination of antibodies and specific antigens via specific antibodies. While selecting the marker molecule, the following parameters were taken into consideration: high enzymatic activity, a wide spectrum of commercially available substrates, considerable thermostability, small size, possibility of the obtaining in bacteria, and stability after conjugation with other proteins. The selection was ended with alkaline phosphatase (AP), widely used to elaborate immunoconjugates for immunochemical methods. Mammalian alkaline phosphatase (MAP) is remarkable for its high $\mathrm{k}_{\text {cat }}$ value (about $2000 \mathrm{~s}^{-1}$ ) and thermolability $\left(\mathrm{T}_{\mathrm{m}} \sim 65^{\circ} \mathrm{C}\right.$ ) [4]. The immunoconjugates with MAP are usually obtained via chemical conjugation [10]. Bacterial alkaline phosphatase (BAP) is less active compared to MAP, its $\mathrm{k}_{\text {cat }}$ value being $65-80 \mathrm{~s}^{-1}$, but it is more thermostable $-\mathrm{T}_{\mathrm{m}}$ is $95^{\circ} \mathrm{C}$. The immunoconjugates with BAP can be obtained by traditional chemical conjugation and in a more convenient way, i.e. by gene engineering combination of BAP sequence and the sequence of the marker molecule. High thermostability, the capability to forming gene-engineered conjugation as well as the possibility of efficient obtaining such conjugates in the active form via bacterial expression make BAP a promising alternative to MAP. Therefore, we preferred BAP as a marker molecule with the increased catalytic activity (BAPmut).

The comparative analysis of the structure of active sites of MAP and BAP demonstrated aminoacid substitutes, highly improving the catalytic activity of the latter. For instance, the aminoacid substitutes $\mathrm{K} 328 \mathrm{H} / \mathrm{D} 330 \mathrm{~N}$ increase the enzymatic activity of BAP three-fold, D153H/K328H, D153H/K328H/D330N eight-fold, D153H/D330N - up to 17-fold. However, along with the enzymatic activity majority of the

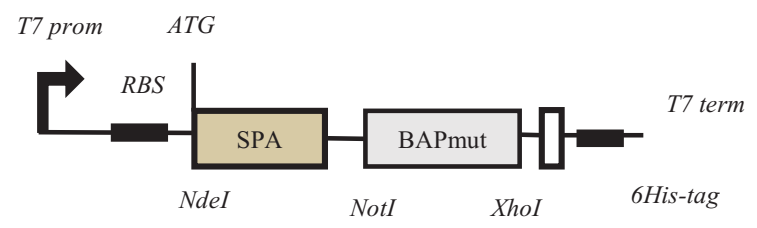

Fig. 1. The scheme of location of the elements of the expression cassette of SPA-BAPmut in vector $p E T-24 a(+)$

mentioned mutations lead to considerable decrease in the thermostability of the enzyme, which decreases the value of the latter as a component of immunoreagents. Mutations D330N/D153G were found, which increase the catalytic activity of BAP by about 17-40 times (depending on the incubation medium content) and do not impact the enzyme thermostability [4]. BAP with the abovementioned properties (aminoacid substitutes D330N/D153G) was used to obtain SPA-BAPmut.

The interactive design of the chimeric protein was conducted considering structural specificities of both moieties of SPA-BAPmut and the topology of their active sites. It was determined that optimal design of the chimeric protein presupposes fusion of BAPmut with $\mathrm{C}$-terminus of SPA. This location secures the functional properties of phosphatase, as $\mathrm{C}$ - terminus, participating in the formation of the molecule active site, is not involved. The abovementioned location of SPA relative to the enzyme does not hinder the dimerization of a phosphatase molecule, required for its functioning, and increases the avidity of the formed immunoconjugate, thus increasing its sensitivity (Fig. 1). At the same time the location of the phosphatase on the N-terminus of the fused partner is a reason of of the loss of functional activity of the latter [11].

For large-scale production of SPA-BAPmut E. coli cells, strain BL21 (DE3), were transformed by the plasmid vector $p E T-24-S P A-B A P m u t$ (Materials and Methods). Expression of SPA-BAPmut was induced by the autoinduction protocol [6]. The electrophoretic analysis of the lysates of bacterial cells demonstrated the band of expected molecular mass ( $78 \mathrm{kDa})$ (Fig. 2). The electrophoretic separation of soluble and insoluble fractions of cytoplasm proteins showed that SPA-BAPmut is synthesized in the soluble form, the level of its accumulation is $37 \%$ of the total proteins of E. coli cells $(\sim 0.96 \mathrm{~g} / 1$ of the bacterial culture) at the optic density $\mathrm{A}_{600}=16.3$. This value is almost 45 times 


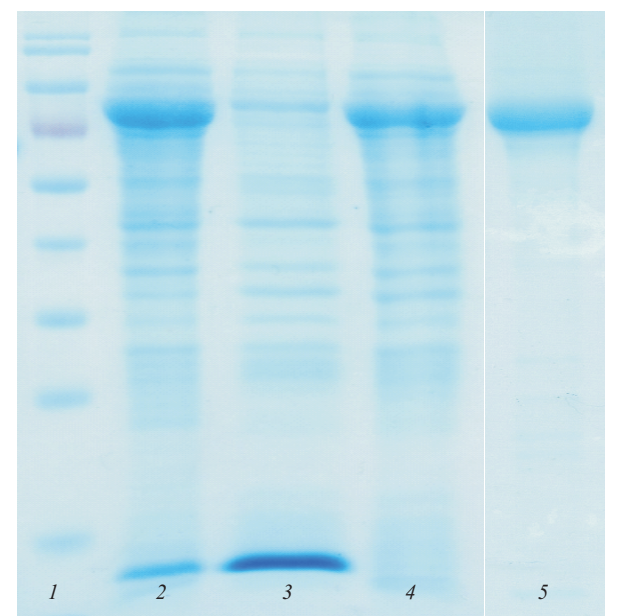

Fig. 2. The expression of SPA-BAPmut in E. coli cells: 1 - molecular weight markers $(130,100,70,55,40,35,25,15$ and $10 \mathrm{kDa}) ; 2$ - total lysate of producent cells with induced production of SPA-BAPmut; 3 fraction of insoluble proteins of the cell; 4 - fraction of soluble proteins of the cell; 5 - SPA-BAPmut, isolated on metal affinity sorbent and dialyzed against the buffer of $0.1 \mathrm{M}$ tris- $\mathrm{HCl}, 0.14 \mathrm{M} \mathrm{NaCl}, 15 \mathrm{mM}$ $\mathrm{MgSO}_{4}, \mathrm{pH} 9.5$

higher than the yield of similar fusion protein SPA APK328A, the obtaining of which is described [12].

The isolation of such conjugates requires combinations of the following methods: cells disruption by sonication, centrifugation, ion-exchange chromatography, gel-filtration, chromatography of hydrophobic interactions, precipitation, affinity chromatography, which, it should be noted, is the reason of the decrease in the functional activity of the enzyme due to strict elution conditions. As SPA-BAPmut contains a genetically introduced His-tag sequence, it was purified using IMAC under native conditions. To decrease nonspecific adsorption of contaminant proteins, which may have significant impact on the purity of the final product, the column was washed with the buffer, containing $300 \mathrm{mM} \mathrm{NaCl}$ and $10 \mathrm{mM}$ imidazole.

The elution of SPA-BAPmut was conducted with the buffer, which contained $300 \mathrm{mM}$ imidazole. The mentioned conditions ensure obtaining SPA-BAPmut with purity more than $\sim 95 \%$ (Fig. 2). After the purification SPA-BAPmut was dialyzed against the buffer, optimal for maintenance of the enzymatic activity of alkaline phosphatase (Materials and Methods).

The data, summarized according to the results of purification of SPA-BAPmut with using IMAC are presented in the Table. It was demonstrated that this method ensures obtaining SPA-BAPmut without
Purification of SPA-BAPmut on Ni-NTA sepharose

\begin{tabular}{c|c|c|c}
\hline Fraction & $\begin{array}{c}\text { Volume, } \\
\mathrm{ml}\end{array}$ & $\begin{array}{c}\text { Total } \\
\text { amount of } \\
\text { protein, mg }\end{array}$ & $\begin{array}{c}\text { Functional } \\
\text { activity } \\
\text { BAPmut, \% }\end{array}$ \\
\hline $\begin{array}{c}\text { Soluble cytoplasm } \\
\text { proteins }\end{array}$ & 10 & 6 & 100 \\
$\begin{array}{c}\text { After purification of } \\
\text { SPA-BAPmut on } \\
\text { Ni-NTA sepharose }\end{array}$ & 5,7 & 5,6 & Not \\
determined \\
After the replacement of \\
$\begin{array}{c}\text { the buffer for elution } \\
\text { with the buffer optimal } \\
\text { for BAPmut }\end{array}$
\end{tabular}

considerable loss of the product (yield $\sim 91.6 \%$ ) and its functional activity.

The purified SPA-BAPmut was used as a secondary antibody for the detection of antibodies (ELISA) and antigenes (ELISA, dot-blotting). It was determined that SPA-BAPmut reliably detects IgG in the concentration of $\sim 500 \mathrm{ng} / \mathrm{ml}$ and less than $15 \mathrm{ng} / \mathrm{ml}$ of antigen (rhIFN62b) (Fig. 3, 4). Besides, contrary to most of the immunoenzymatic systems of detection with specific secondary antibodies conjugated with a marker molecule, the application of SPA-BAPmut allows extending the range of primary antibodies (SPA recognizes $\mathrm{Fc}$-fragments of $\mathrm{IgG}$ of humans, mice,rabbits, guinea pigs and bovine).

The thermostability of the fusion protein SPA-BAPmut was also determined. For this reason the aliquotes of SPA-BAPmut with the same concentration were incubated at different temperatures (Materials and Methods). SPA-BAPmut, isolated right prior to the experiment, was used as control. As seen from the diagram, presented in Fig. 5, SPA-BAPmut does not lose its immunoglobulin-binding and phosphatase activity during incubation at the temperature up to $70^{\circ} \mathrm{C}$; it also endures the impact of low temperatures (Fig. 5). High thermostability of SPA-BAPmut is of relevant diagnostic significance as usually commercially available immunoconjugates are rather thermolabile. It was shown that SPA-BAPmut preserves its functional activity for at least 6 months if stored in $50 \%$ glycerol at $4{ }^{\circ} \mathrm{C}$ in the corresponding buffer.

Compared to the analogues, the suggested immunoconjugates has higher sensitivity due to an 

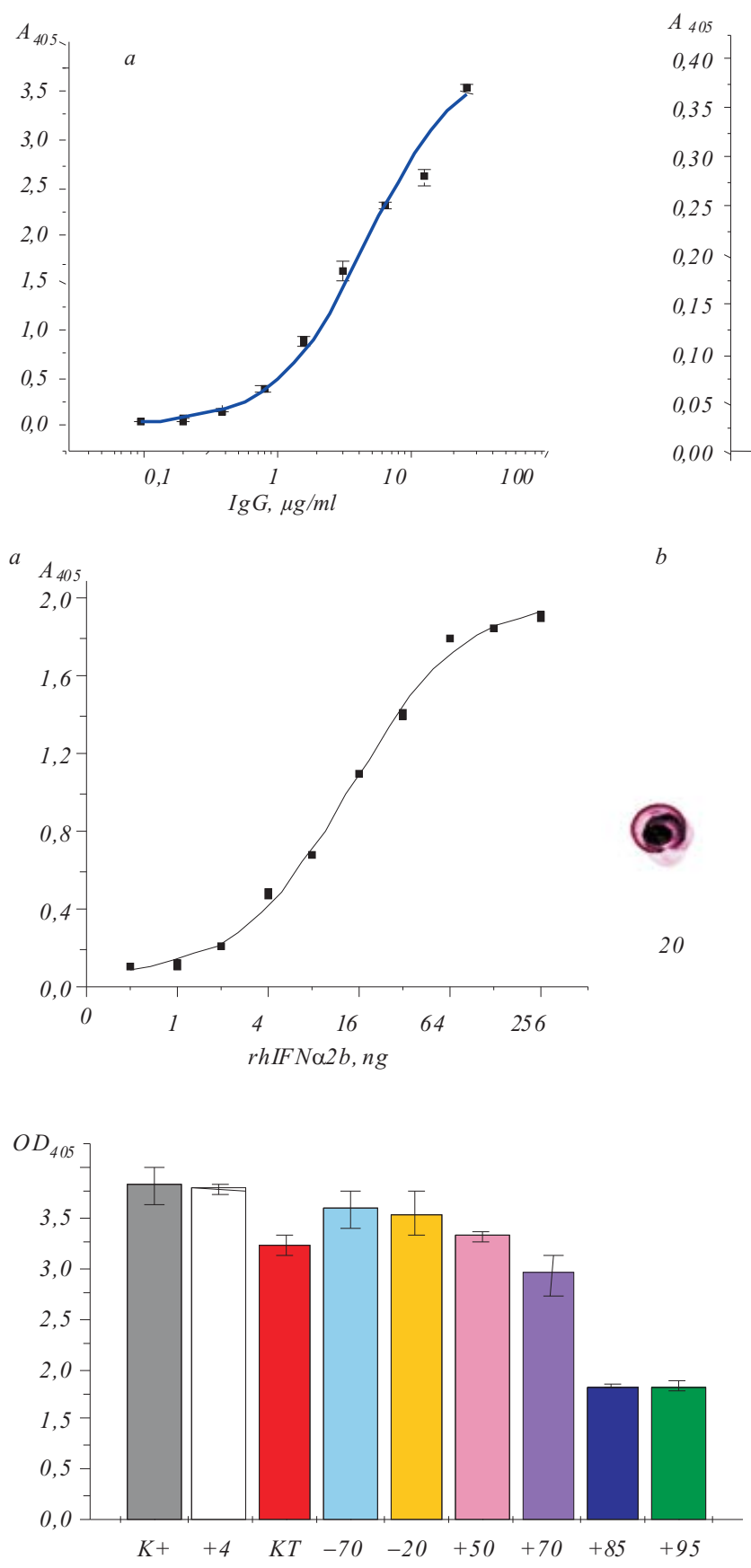

Fig. 5. The impact of different temperatures on functional activity of the fusion protein SPA-BAPmut: $K+-$ SPA-BAPmut immediately after the isolation from $E$. coli cells; $R T$ - room temperature $(24 \mathrm{~h}) ;+4$, $+50,+70,+85,+95,-70,-20^{\circ} \mathrm{C}(10 \mathrm{~min})$

increase in the enzymatic activity of BAP. Besides, contrary to traditional immunoreagents, created by chemical conjugation, the fusion protein SPA-BAPmut, obtained in preparative amounts by high productive and

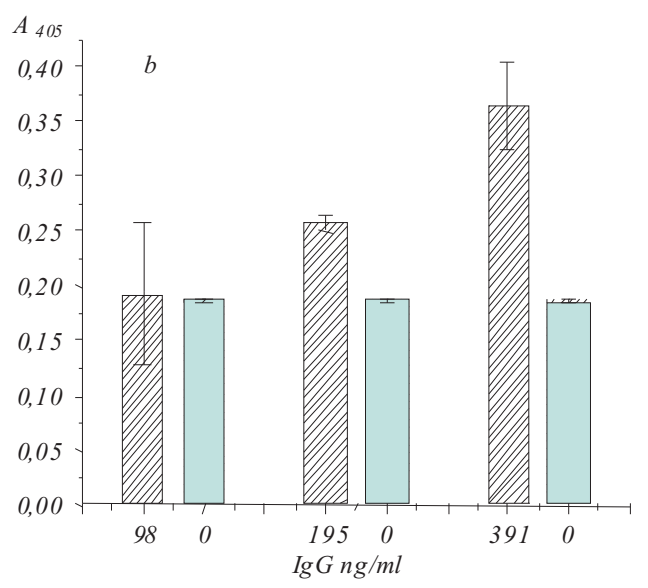

Fig. 3. The determination of the minimal concentration of $\mathrm{IgG}$, detected using SPA-BAPmut in ELISA
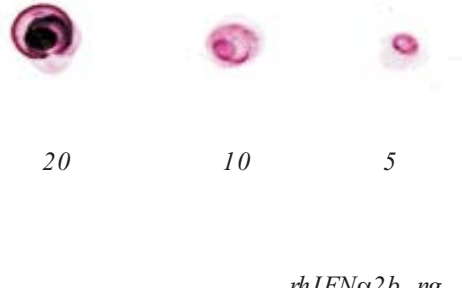

simple bacterial expression, allows for considerable simplification of the laboratory and industrial production of similar immunoreagents and reduction in the cost of immunoconjugates.

О. Б. Горбатюк ${ }^{1}$, О. В. Окунєв ${ }^{1,2}$, Ю. С. Ніколаєв ${ }^{1}$, О. В. Святенко ${ }^{3}$, В. А. Кордюм ${ }^{1,2}$

Конструювання, синтез, функціональна характеристика і практичне застосування злитого білка SPA-BAPmut

${ }^{1}$ Інститут генетичної і регенеративної медицини НАМН України Вул. Червоноармійська, 57/3, Київ, Україна, 03150

${ }^{2}$ Інститут молекулярної біології і генетики НАН України Вул. Академіка Заболотного, 150, Київ, Україна, 03680

${ }^{3}$ Національний авіаційний університет

Пр. Комарова, 1, Київ, Україна, 03058

Резюме

Mета. Створення генно-інженерного злитого білка SPA-BAPтит та його застосування як вторинного імунореагенту в імунологічних тестах. Методи. Клонування генів, ПЛР, секвенування ДНК, культивування бактерій, електрофорез, синтез і очищення білків, ELISA, вестерн-блот. Результати. 3 використанням 
послідовновностей ДНК, щу кодують білок A Staphylococcus aureus (SPA) і бактерійну лужну фосфатазу з покращеними каталітичними властивостями (ВАРтит), сконструйовано ген злитого білка SPA-BAPтит та забезпечено його препаративне отримання у розчинній формі внаслідок синтезу в клітинах Escherichia coli. Визначено умови ферментачіï, за яких вихід SPA-BAPтит становить приблизно 1 г/л культури E. coli. Iз застосуванням методу металоафінної хроматографії одержано иільовий білок з чистотою понад $95 \%$. SPA-BAPтит термостабільний, а обидва його компоненти (SPA і BAPтит) зберігають імуноглобулінзв'язувальну $i$ фосфатазну активність тривалий час. SPA-BAPтит дозволяє виявляти щзонайменше 5 нг антигену та 1 мкг/мл антитіл. Висновки. Показано можливість використання SPA-BAРтит як універсального вторинного імунореагенту в імунохімічних тестах.

Ключові слова: білок А, бактерійна лужна фосфатаза, злитий білок, імунодіагностика.

О. Б. Горбатюк, О. В. Окунев, Ю. С. Николаев, О. В. Святенко, B. А. Кордюм

Конструирование, синтез, функциональная характеристика и практическое применение слитого белка SPA-BAPmut

Резюме

Цель. Создание генно-инженерного слитого белка SPA-ВАРтит и его использование как вторичного иммунореагента в иммунологических тестах. Методы. Клонирование генов, ПЛР, секвенирование ДНК, культивирование бактерий, электрофорез, биосинтез и очистка белков, ELISA, вестерн-блот. Результаты. С использованием последовательностей ДНК, кодируюших белок A Staphylocoсcиs aureus (SPA) и бактериальную щелочную фосфатазу с улучшенными каталитическими свойствами (ВАРтит), сконструирован ген слитого белка SPA-BAPтит и обеспечено его препаративное получение в растворимой форме вследствие синтеза в клетках Escherichia coli. Определень условия ферментации, при котоpых выход SPA-BAPтит составляет около 1 г/л культуры E. coli. C применением метода металлоаффинной хроматографии иелевой белок получен с чистотой более $95 \%$. SPA-BAPтит термостабилен, а оба его компонента (SPA и ВАРтит) сохраняют иммуноглобулинсвязываюшую и фосфатазную активность на протяжении длительного времени. SРА-ВАРтит позволяет детектировать 5 нг антигена и 1 мкг/мл антител. Выводы. Показана возможность применения SPA-BAPтит как универсального вторичного иммунореагента в иммунохимических тестах.

Ключевые слова: белок А, бактериальная щчелочная фосфатаза, слитый белок, иммунодиагностика.

\section{REFERENCES}

1. Moks T., Abrahmsen L., Nilsson B., Hellman U., Sjoquist J., Uhlen $M$. Staphylococcal protein A consists of five IgG-binding domains // Eur. J. Biochem.-1986.-156, N 3.-P. 637-643.

2. Hober S., Nord K., Linhult M. Protein A chromatography for antibody purification // J. Chromatogr. B. Analyt. Technol. Biomed. Life Sci.-2007.-848, N 1.-P. 40-47.

3. Doesch A. O., Mueller S., Konstandin M., CelikS., Frankenstein L., Zugck C., Dengler T. J., Fleming T., Bierhaus A., Katus H. A. Effects of protein A immunoadsorption on methylglyoxal levels in patients with chronic dilated cardiomyopathy and diabetes me1litus // Appl. Cardiopulm.Pathophysiol.-2011.-15.-P. 3-13.

4. Muller B. H., Lamoure C., Le Du M. H., Cattolico L., Lajeunesse E., Lemaitre F., Pearson A., Ducancel F., Menez A., Boulain J. $C$. Improving Escherichia coli alkaline phosphatase efficacy by additional mutations inside and outside the catalytic pocket // Chembiochem.-2001.-2, N 7-8.-P. 517-523.

5. Gorbatiuk O. B., Tsapenko M. V., Pavlova M. V., Okunev O. V., Kordium V. A. Bioaffinity sorbent based on immobilized protein A Staphylococcus aureus: development and application // Biopolym. Cell.-2012.-28, N 2.-P. 141-148.

6. Studier $F$. $W$. Protein production by auto-induction in high density shaking cultures // Protein Expr. Purif.-2005.-41, N 1.P. 207-234.

7. Westermeir R. Electrophoresis in practice: a guide to methods and application of DNA and protein separations.-Weinheim: VCH, 1997.-331 p.

8. Okunev O. V., Gilchuk P. V., Irodov D. M., Deryabina O. G. Obtainaing and characterization of the single chain antibodies against human $\alpha 2 \beta$-interferon. // Ukr. Biochem. J.-2005.-77, N 5.P. 106-115.

9. Nikolaiev Iu. S., Gorbatiuk O. B., Tsapenko M. V. The development of strategy for obtaining single-chain recombinant antibodies against cell-surface biomarkers on the example of human CD34 // Biopolym. Cell.-2010.-26, N 6.-P. 492-498.

10. Nilson B., Bjorck L., Akerstrom B. Enzyme linked immunosorbent assay using alkaline phosphatase conjugated with streptococcal protein G // J. Immunoassay.-1988.-9, N 2.-P. 207-225.

11. Zhang L., Buchet R., Azzar G. Distinct structure and activity recoveries reveal differences in metal binding between mammalian and Escherichia coli alkaline phosphatases // Biochem. J.-2005.-392, Pt 2.-P. 407-415.

12. Chowdhury P. S., Kushwaha A., Abrol S., Chaudhary V. K. An expression system for secretion and purification of a genetically engineered thermostable chimera of protein A and alkaline phosphatase // Protein Expr. Purif.-1994.-5, N 1.-P. 89-95. 